\title{
The Effect Of Continuity Of Care Against Weight and Length Of Newborn Body In Rejoyoso Village
}

\author{
Nurya Viandika*, Alifia Candra Puriastuti \\ STIKes Widya Cipta Husada Malang \\ viandika04@gmail.com
}

\begin{abstract}
Stunting is still a nutritional problem for the community both at national and international levels. long and low birth weight history in is one of the risk factors of stunting. This research identifies whether there is an effect of continuity of care on length and birth weight. So that you can get a way to prevent stunting as early as possible. This research was conducted in Rejoyoso Village with a population of mothers who have babies aged 06 months, with a retrospective approach and the source of research data is the maternat book record. The research data were analyzed by chi square, and the result of birth length $\mathrm{x}^{2}$ count 5,605> $\mathrm{x}^{2}$ table 3,841 and the result of birth weight $\mathrm{x}^{2}$ count 5,029> $\mathrm{x}^{2}$ table 3,841. So the interpretation obtained from each variable is rejecting $\mathrm{H} 0$ or there is a continuity of care effect on length and birth weight. Early monitoring can identify the incidence of failure to thrive so that immediate intervention can be given.
\end{abstract}

Keywords : Continuity Of Care, Length Of Newborn, Weight Of Newborn 


\section{STRADA Jurnal Ilmiah Kesehatan}

DOI: $10.30994 /$ sjik.v9i1.254

ISSN: 2252-3847 (print); 2614-350X (online)

Vol.9 No.1. May 2020. Page.219-223

\section{INTRODUCTION}

Birth length and birth weight describe the linear growth of the baby during the womb. Low linear size usually indicates a lack of nutrition due to lack of energy and protein suffered a long time ago. Long history and low birth weight in other words LBW is one of the risk factors of stunting (Supariasa et al., 2012). The continuation is that the baby will experience growth and development slower than babies born normally, and often fails to follow the level of growth that he should have reached after his birth (Proverawati, 2010). This is in line with the results of the study (Atikah Rahayu, 2015) which found that stunting experienced by children aged under two years was due to the child having a low birth weight at birth $(<2,500$ grams $)$.

Stunting is one indicator of chronic nutritional status that illustrates stunted growth due to long-term malnutrition, stunting will only appear after the baby is 2 years old (Rahmadi, 2016). According to the Decree of the Minister of Health of the Republic of Indonesia Number 1995 / MENKES / SK / XII / 2010 concerning Anthropometry Standards for the Assessment of Child Nutrition Status, stunting is a nutritional status based on the Body Length index by Age (PB / U) or Height by Age (TB) / U) which is a term of stunted (short) and severely stunted (very short) (Kemenkes RI, 2010). Until now stunting is still a nutritional problem for the community both at national and international levels (Rahmadi, 2016).

Efforts that can be made to prevent the occurrence of long and low birth weight and even reduce the prevalence of stunting are by conducting continuous care or commonly called continuity of care (COC). Continuity of Care is done since the mother during pregnancy. Continuous midwifery care provided to mothers since pregnancy can detect early and prevent possible complications that can cause LBW events, so these complications can be treated early. By doing this Continuity Of Care treatment, it is hoped that it can reduce the number of stunting events.

\section{METHODS}

This research was conducted on December 17, 2019 together with the Exclusive ASI Counseling Activity in Rejoyoso Village. This research is an observational analytic study with a retrospective approach. The number of samples is 16 mothers who have babies and toddlers aged 0-6 months at the time the data collection took place. The data source of this research is secondary data, namely the $\mathrm{MCH}$ book. The sampling technique used in this study is to use purposive sampling by taking samples that fit the inclusion and exclusion criteria. Data analysis was carried out by computerization using the SPSS program which is a type of non-parametric statistics with Chi Square correlation.

\section{RESULTS}

\section{General characteristics of respondents}

Tabel 1. characteristics of respondents

\begin{tabular}{crcc}
\hline Age & & & \\
\hline Number. & Age & Amount & Percentage \\
$1 . \quad<20$ years & 1 & $6,25 \%$ \\
$2 . \quad \geq 20-\leq 35$ years & 14 & $87,5 \%$ \\
$3 . \quad>35$ years & 1 & $6,25 \%$ \\
Profession & & \\
$1 . \quad$ Housewife & 11 & $68,8 \%$ \\
\hline
\end{tabular}




\begin{tabular}{clcc}
\hline 2. & Working & 5 & $31,2 \%$ \\
$\begin{array}{clc}\text { Education } \\
\text { 1. }\end{array}$ & Elementary school & 3 & $18,8 \%$ \\
2. & Secondary school & 6 & $37,5 \%$ \\
3. & Senior High school & 7 & $43,8 \%$ \\
Paritas & & & \\
1. & Primipara & 12 & $75 \%$ \\
2. & Multipara & 4 & $25 \%$ \\
\hline
\end{tabular}

1. Continuity of Care to length of newborn and weight of newborn

Table 2. Continuity of Care to length of newborn cross table

\begin{tabular}{lcccc}
\hline & & \multicolumn{2}{c}{ length of newborn } & Amoun \\
\multirow{3}{*}{$\begin{array}{l}\text { Continuity of } \\
\text { Care }\end{array}$} & Irreguler & 4 & 1 & $\mathrm{t}$ \\
\multicolumn{2}{c}{ Under Normal } & Normal & 5 \\
& Continue & 2 & 9 & 11 \\
& Amount & 6 & 10 & 16 \\
\hline
\end{tabular}

When tabulated using the $2 \times 2$ cross table, it appears that Continuity of Care affects the length of the birth body, as stated in table 2 .

Table 3. Continuity of Care weight of newborn cross table

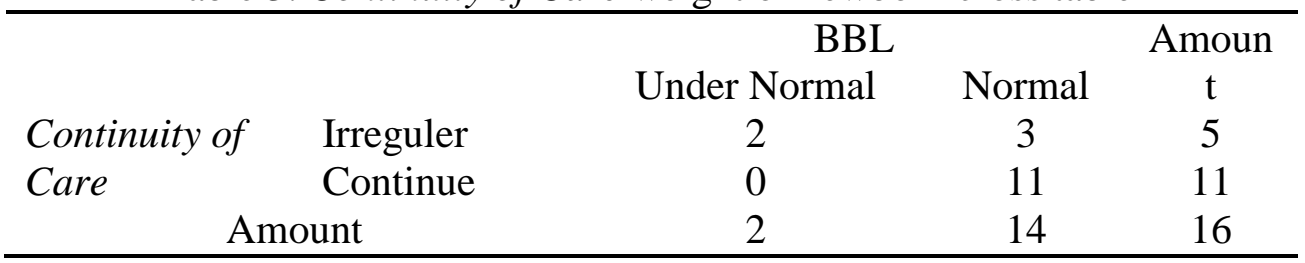

Likewise with birth weight, tabulation shows Continuity of Care influences birth weight, as stated in table 3 .

Table 4. Continuity of Care to length of the birth body and weight of birth corelation

\begin{tabular}{|l|c|c|c|c|l|}
\hline & $\mathrm{x}^{2}$ hitung & $\mathrm{x}^{2}$ tabel & Asymp.sig & $\alpha$ & \multicolumn{1}{c|}{ conclusion } \\
\hline Length & 5,605 & \multirow{2}{*}{3,841} & 0,018 & \multirow{2}{*}{0,05} & $\mathrm{H}_{0}$ rejected \\
\cline { 1 - 1 } Weight & 5,029 & & 0,025 & & $\mathrm{H}_{0}$ rejected \\
\hline
\end{tabular}

While statistically, it appears in table 4 that Continuity of Care affects the length of the birth body and birth weight. Namely obtained $x 2$ count $>x 2$ table, then it can be interpreted to reject $\mathrm{H} 0$.

\section{DISCUSSION}

Continuous care or called the Contiunity of care (COC), which is care that is comprehensively given to mothers since pregnancy, childbirth, childbirth, newborns, and family planning, and is given in a continuous place including home visits, communities, health centers and places referral (Rahma, 2015). According to Gulliford in Liao (2018), $\mathrm{COC}$ is recommended as an essential element in the health care system. The basic thing in COC is unlimited service through integration, coordination and information sharing between several different providers. 


\section{STRADA Jurnal Ilmiah Kesehatan}

DOI: $10.30994 /$ sjik.v9i1.254

Continuous care during pregnancy is important to optimize monitoring of pregnancy progress to ensure the health of the mother and the development of the baby. In addition to monitoring the growth and development of infants, COC also aims to increase the independence and empowerment of mothers. The educational characteristics of the respondents are at least elementary (18.8\%) and highest high school (43.8\%), so information provided to mothers is expected to be easily accepted. Most respondents also showed primiparous characteristics (75\%). Thus increasing mother's knowledge and continuous monitoring is felt right on target. However, not all respondents have done COC, the results of the study still showed that $30 \%$ of respondents did not meet the standard of pregnancy visits so COC was not optimal.

One indicator of infant growth is based on length and birth weight. The results showed that most babies were of normal weight and length of birth. The results of cross tables and statistics that link COC to the long weight of newborns, show the influence of COC on PBL and BBL. This can be due to optimal supervision of the condition of the mother during pregnancy. The condition of the mother during pregnancy is monitored through the $\mathrm{MCH}$ book. Where even though the mother moved or the service provider of the visit of pregnant women, the history and condition of the latest maternal pregnancy still recorded in the MCH handbook.

In addition to monitoring during pregnancy, further monitoring is on newborns, one of which is the length and weight of the newborn baby. The length and weight gain of the baby is monitored every month to determine the growth prognosis of the baby. Human growth is a result of interactions between genetic factors, hormones, nutrients, and energy with environmental factors. Growth failure can occur during gestation (pregnancy) and in the first 2 years of a child's life or during the first 1000 days of a child's life (Sandra Fikawati et al, 2017). Knowing early growth failures that occur, namely by detecting the length and weight of a newborn baby, then handling and preventing stunting can be done early.

\section{CONCLUSION}

Continuity of Care affects the length and weight of newborn babies in the Rejoyoso village, Wonokerto Public Health Center, Bantur District, Malang Regency. Early monitoring can identify the incidence of failure to thrive so that immediate intervention can be given. This monitoring continues into infancy.

\section{REFERENCES}

Atikah Rahayu, F. Y. (2015). Riwayat Berat Badan Lahir dengan Kejadian Stunting.

Diana, Sulis. (2017). Model Asuhan Kebidanan Continuity Of Care. Surakarta: CV Kekata Group.

Depkes.(2013). Profil Kesehatan Indonesia. Jakarta: Depkes. HYPERLINK "http://www.depkes.go.id" http://www.depkes.go.id

Liao, Yao, Qiaomiao Zeng, Yu Xu, and Qian Yang (2018). A Concept Analysis of Continuity of Care in Nursing. Journal of Pharmacy and Pharmacology (6)

Juaria, Henry, 2014. Hubungan antara umur dan paritsa dengan kejadian berat badan lahir rendah Maret 2014. Volume 3, pp. 48-50

Lusiana, dkk. (2019). Pengaruh Continuity of Care (COC) pada Asuhan Kebidanan Masa Postpartum Terhadap Kecenderungan Depresi Postpartum pada Ibu Nifas 
Mella, E. R. (2018). Pelatihan Siswa "Dokter Kecil" Dengan Metode Simulasi Untuk Meningkatkan Keterampilan Menilai Status Gizi Di Kecamatan Moyudan.

Modul A Pelatihan Penilaian Pertumbuhan Anak, Direktorat Bina Gizi, Kemenkes RI, 2011

Proverawati, A. \&. (2010). Berat Badan Lahir Rendah. Yogyakarta: Nuha Medika.

Rahmadi, A. (2016). Hubungan Berat Badan Dan Panjang Badan Lahir Dengan Kejadian Stunting Anak 12-59 Bulan Di Provinsi Lampung . Jurnal Keperawatan, Volume XII, No 2 .

Susilowati, E. (2018). Faktor Risiko Kejadian Stunting pada Bailta 1-5 tahun di Puskesmas Bangsri I Kabupaten Jepara .

Pramuditya SW. 2010. Kaitan Antara Tingkat Pendidikan dan Pengetahuan Gizi Ibu,Serta Pola Asuh dengan Perilaku Keluarga Sadar Gizi dan Status Gizi, Bogor : Departemen Gizi Masyarakat Dan Sumberdaya Keluarga, Fakultas Pertanian, Institut Pertanian Bogor

Purwaseh, O. E. (2019). Asuhan Kebidanan pada Ny. N Masa Hamil Sampai Dengan Pelayanan keluarga Berencana Di PMB Suprapti S.ST., M.Kes Domas Menganti gresik.

Rahma,Marliana, 2015. Asuhan Berkesinambungan Untuk Menigkatkan Kesehatan Ibu Dan Bayi Di Kabupaten Subang. Akademi kebidanan Bandung JL. Garuda no 79 Bandung, Indonesia

Rahmawati, R. I. (2018). Hubungan Tingkat Pendidikan Dan Riwayat Antenatal Care (Anc) Dengan Tindakan Sectio Caesarea. 1-10. 